\title{
Development of Evaluation System for Defense Informatization Level
}

\author{
Seungbae $\operatorname{Sim}^{1}$, Sangho Lee $2^{*}$
}

\begin{abstract}
There is a description that you cannot manage what you do not measure. The Korea Ministry of National Defense (MND) is conducting evaluations in various fields to obtain meaningful effects from IT investments, and views that the evaluation of the defense informatization sector is divided into defense informatization policy evaluation and defense informatization project evaluation. The defense informatization level evaluation can measure the informatization level of MND and the armed forces or organizations. Since the evaluation system being studied to measure the level of defense informatization is composed mainly of qualitative metrics, it is necessary to reconstruct it based on quantitative metrics that can guarantee objectivity. In addition, for managing the level of change by evaluation objects, the evaluation system should be designed with a focus on homeostasis of metrics so that it can be measured periodically. Moreover, metrics need to be promoted in terms of performance against targets. To this end, this study proposes to measure the level of defense informatization by dividing it into defense information network, computer systems, interoperability and standardization, information security, information environment, and information system use, and suggests their metrics.
\end{abstract}

Key Words: Defense Informatization Level, Evaluation Metric, Informatization Performance, IT Effect.

\section{INTRODUCTION}

"You can't manage what you don't measure." This sentence is alleged to have been claimed by Edward Deming or Peter Drucker [1] and explains the importance of measurement. The Korea Ministry of National Defense (MND) is conducting evaluations in various fields to obtain meaningful effects from IT investment. The evaluation in the defense informatization sector is divided into defense informatization policy evaluation and defense informatization project evaluation [2], [3]. The defense informatization policy evaluation assesses various policies of MND and military forces related to the defense informatization, and the defense informatization project evaluation assesses IT projects such as information system (IS) development projects, IT procurement projects, and IS operation projects that are being carried out by the MND, Army, Navy, and Air Force [4]. On the other hand, the defense informatization level evaluation can measure the informatization level such as the informatization capacity of the MND and the related organizations or agencies.
Defense informatization aims to achieve military missions and create results by utilizing information technology. If the level of defense informatization associated with input or process factors is improved, the outcome factor, which is a performance or net effect, can be improved. The purpose of measuring the level of informatization can be improving the level of informatization (input or process factors) apart from the performance management of informatization (output factors).

This study proposes the evaluation system to measure the level of defense informatization in terms of defense information network, computer systems, interoperability and standardization, information security, informatization environment, and IS use, and also describes quantitative evaluation metrics in each field.

\section{RELATED WORKS}

\subsection{Information Systems Success Model}

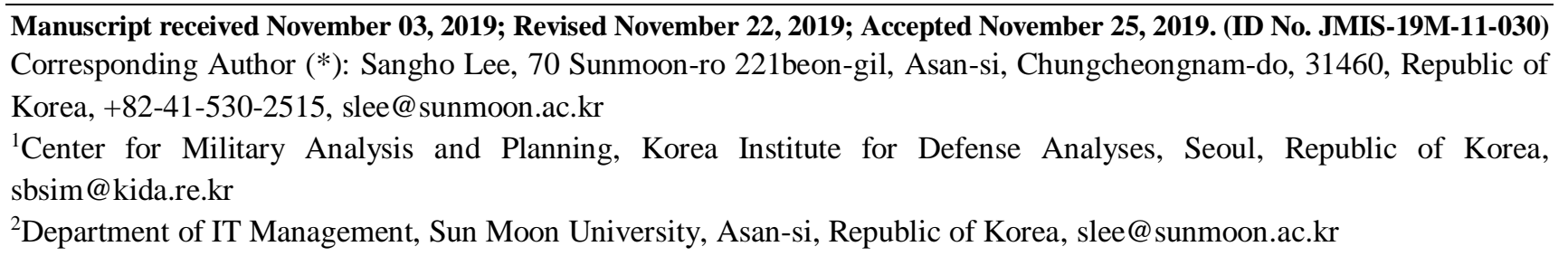


DeLone and McLean [5] suggested an information systems (IS) success model (Fig. 1) after reviewing various existing researches related to IS performance. The model suggests that both IS quality and information quality affect both IS use and user satisfaction, that both IS use and user satisfaction affect the individual performance of IS, and that the individual performance lastly affects organizational performance. In addition, the IS use affects and is affected by the user satisfaction. In the view of the IS success model, the IS performance depends on IS quality and information quality, which is related to an input factor, IS use and user satisfaction, which is a process factor.

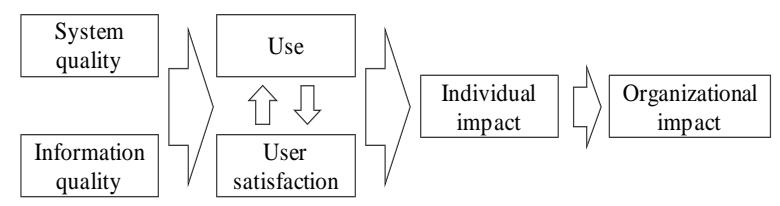

Sources: DeLone and McLean [5, p. 87], Fig. 2.

Figure. 1. DeLone and McLean's IS success model

DeLone and McLean [6] reviewed the many empirical studies applied with their model [5], and suggested updated IS success model (Fig. 2). They included service quality and intention to use in their IS success model [5] and added a feedback from net benefits to the intention to IS use and the user satisfaction. In the view of the updated IS success model, the net benefits (performance) depends on IS quality, information quality, service quality, intention to use, use, and user satisfaction. This model focuses quality of systems, information, service, IS use, user satisfaction as an informatization level.

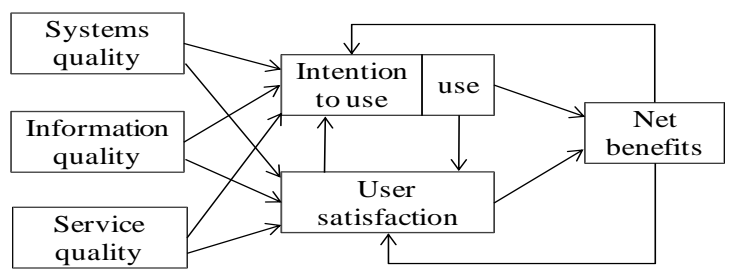

Sources: DeLone and McLean [6, p. 24], Fig. 3.

Figure. 2. DeLone and McLean's updated IS success model.

\subsection{ITU ICT Development Index}

International Telecommunication Union (ITU) measures the level of informatization for each country by calculating the Information and Communication Technology Development Index (IDI) [7, 8, 9]. IDI is measured in Information and Communication Technology (ICT) access, ICT use, and ICT skills. ICT access measures the fixedtelephone subscriptions per 100 inhabitants, the mobilecellular telephone subscriptions per 100 inhabitants, the international Internet bandwidth (bit/s) per Internet user, the percentage of households with a computer, and the percentage of households with Internet access.

ICT use applies metrics such as the percentage of individuals using the Internet, the fixed-broadband subscriptions per 100 inhabitants, and the active mobilebroadband subscriptions per 100 inhabitants. ICT skills uses the metrics of the adult literacy rate, the secondary gross enrolment ratio, and the tertiary gross enrolment ratio.

The weights for ICT access, ICT use, and ICT skills are $40 \%, 40 \%$, and $20 \%$, respectively. The same weights are assigned to the metrics within each item. In 2017, ITU member countries decided to revise and expand the IDI [10], but the results have not yet been published as of October 2019. Infrastructure, use, and skills (user capability) are evaluated in the IDI.

\subsection{Evaluation Method of Korean Government}

The Korean government's evaluation of informatization capability (level) is being implemented as part of the evaluation of administrative management capability to improve the system in the informatization field [11]. This evaluation is managed by the Ministry of the Interior and Safety, which is based on the Framework Act on Public Service Evaluation [12]. Organizations to be evaluated are 44 central government departments including the MND.

Table 1. Metrics for national informatization level evaluation in Korea.

\begin{tabular}{|c|c|c|}
\hline Type & Evaluation metric & Weight \\
\hline \multirow{7}{*}{$\begin{array}{l}\text { Implemen- } \\
\text { tation of } \\
\text { effective e- } \\
\text { government } \\
\text { (20 points) }\end{array}$} & $\begin{array}{l}\text { Propulsion of performance } \\
\text { management of e-government }\end{array}$ & 14 \\
\hline & $\begin{array}{l}\text { Measurement of information } \\
\text { resource management level }\end{array}$ & 3 \\
\hline & $\begin{array}{l}\text { Implementation level of phased } \\
\text { performance management }\end{array}$ & 7 \\
\hline & Prevention of redundant investment & 4 \\
\hline & $\begin{array}{c}\text { Efficiency of website operation } \\
\text { management }\end{array}$ & 6 \\
\hline & Web compatibility/access level & 3 \\
\hline & Website plug-in removal ratio & 3 \\
\hline \multirow{6}{*}{$\begin{array}{l}\text { Reinforce- } \\
\text { ment of } \\
\text { cyber safety } \\
\text { level } \\
\text { (15 points) }\end{array}$} & Privacy protection level & 4 \\
\hline & $\begin{array}{lcc}\text { E-government civil } & \text { service } \\
\text { information security level } & \\
\end{array}$ & 4 \\
\hline & Cyber security management level & 6 \\
\hline & $\begin{array}{l}\text { Administrative information security } \\
\text { level }\end{array}$ & 3 \\
\hline & $\begin{array}{c}\text { Cyber crisis management and } \\
\text { technical information security level }\end{array}$ & 3 \\
\hline & Cyber-attack response training result & 1 \\
\hline
\end{tabular}

The Ministry of the Interior and Safety conducts a preliminary evaluation of the informatization field with the National Information Society Agency (NIA), and notifies the preliminary evaluation results to each central 
government department. The central administrative departments finally evaluate their informatization level themselves with the results.

The evaluation system of the informatization field in 2019 shows that a perfect score is 35 points, and measures the implementation of effective e-government (20 points) and the reinforcement of cyber safety level (15 points). Evaluation metrics and their weights are shown in Table 1. The evaluation system also describes the evaluation formula as well as the evaluation method for each metric [11].

A survey on informatization level for small and medium enterprises (SMEs) is conducted by the Ministry of SMEs and Startups and Korea Technology \& Information Promotion Agency for SMEs. This survey is for establishing informatization strategies and establishing policy directions for supporting SMEs [13]. It examines the general status of companies, the willingness and plans for informatization reinforcement, the environment for informatization reinforcement, the current status of IS implementation and use, the level of informatization effectiveness, and smart factories and new ICT technologies. Since 2012, the evaluation of SMEs informatization level has not been carried out using all the surveyed items, but only three items: the willingness and plans for informatization reinforcement, the environment for informatization reinforcement, and the current status of IS implementation and use.

Many researches have been conducted on the evaluation system for defense informatization level and the metrics for each item. Lim et al. [14] suggest to measure the level of defense informatization in terms of informatization infrastructure, informatization environment, informatization use, and informatization performance. In the informatization infrastructure, defense information network, computer systems, interoperability and standardization are measured. In the informatization environment, information security, organization, education, investment, and strategy of informatization are measured. The use of informatization measures the use of battlefield management information system (MIS) and resource MIS. The informatization performance measures the level of informatization combat power and the improvement of the efficiency of defense management. Also, various evaluation metrics are presented in the study [14]. The weights of evaluation items or metrics were calculated using Analytic Hierarchy Process (AHP). It is speculated that a method of calculating the evaluation metrics may have been developed, but the study [14] did not provide it. In order to demonstrate the usability of the developed evaluation system for defense informatization level, the informatization level was measured for military units in the operation command or higher with surveys on current status and questionnaires.

For other methods of informatization level measurement, such as the corporate informatization level evaluation, and a survey on the SMEs informatization level prior to 2012, refer the existing study [14].

Since the evaluation system of defense informatization level is mainly composed of qualitative evaluation metrics, it is necessary to reconstruct it based on quantitative evaluation metrics that can guarantee objectivity [15]. It should be able to manage the increase and decrease of the level by evaluation area. It should be designed with a focus on homeostasis of metrics so that it can be measured periodically. In addition, it is necessary to refrain from evaluating all evaluation metrics using the 5-point scale without a clear comparison, and to promote the evaluation in terms of achieved performance against targets. The method of measuring the informatization level with a questionnaire is simple, but there are limitations. This may be a subjective result by the survey respondent's perception rather than an objective one. The informatization level may be measured differently by the change of the survey respondent even though the organization or institution was the same informatization level. Longitudinal analysis also needs to be available for level improvement or trend analysis.

The level evaluation can be performed in the manner of improvement of metrics compared to the previous year, the level comparison to domestic or overseas organizations (institutes), and absolute maturity level. In the short term, it is advisable to conduct a level assessment in order to compare the level of metric improvement compared to the previous year or to compare the level of metrics with other organizations. To use the evaluation system for the informatization maturity level, at least several years of data must be accumulated and available.

\section{EVALUATION FOR DEFENSE INFORMATIZATION LEVEL}

This study describes an evaluation system for measuring the level of defense informatization. Defense informatization level assessment can be classified into IT infrastructure, informatization environment, and IS use according to the domain of evaluation (Table 2). In particular, the level assessment for IT infrastructure is evaluated by subdividing it into areas such as Defense information network (A), Computer systems (B), Interoperability and standardization $(\mathrm{C})$, and Information security(D) [15]. In the Defense information network (A), speed, traffic, and availability/recovery time are measured. Server utilization, server availability, server throughput, 
and work efficiency are measured in Computer systems (B). Interoperability among ISs, standardization of reference information (master data), and interoperability between weapon systems and IS are measured in Interoperability and standardization (C). The detection level (capability) of infringement incident, the response level (capability) of infringement incident, and the recovery of infringement incident are measure in Information security (D).

Table 2. Evaluation metrics for defense informatization level.

\begin{tabular}{|c|c|}
\hline Item & Metric \\
\hline \multicolumn{2}{|c|}{ IT infrastructure - Defense information network(A) } \\
\hline Speed(A.1) & $\begin{array}{l}<\text { A-1-1> Average speed among main } \\
\text { nodes } \\
<\text { A-1-2> Average speed between main } \\
\text { node and secondary node (branch line) } \\
<\text { A-1-3> Average speed between } \\
\text { secondary node and user }\end{array}$ \\
\hline Traffic(A.2) & $\begin{array}{l}<\text { A-2-1> Average traffic among main } \\
\text { nodes } \\
<\text { A-2-2> Average traffic between main } \\
\text { node and secondary node (branch line) } \\
<\text { A-2-3> Average traffic between } \\
\text { secondary node and user }\end{array}$ \\
\hline $\begin{array}{l}\text { Availability/ } \\
\text { recovery time } \\
\text { (A.3) }\end{array}$ & $\begin{array}{l}<\text { A-3-1> Network availability } \\
<\text { A-3-2> Recovery time }\end{array}$ \\
\hline \multicolumn{2}{|c|}{ IT infrastructure - Computer systems(B) } \\
\hline $\begin{array}{l}\text { Server } \\
\text { utilization(B.1) }\end{array}$ & $\begin{array}{l}<\mathrm{B}-1-1>\text { Average (maximum) CPU use } \\
\text { ratio } \\
<\mathrm{B}-1-2>\text { Average storage use ratio }\end{array}$ \\
\hline $\begin{array}{l}\text { Server } \\
\text { availability } \\
\text { (B.2) }\end{array}$ & $\begin{array}{l}<\mathrm{B}-2-1>\text { Server availability } \\
<\mathrm{B}-2-2>\text { Server recovery time }\end{array}$ \\
\hline $\begin{array}{l}\text { Server } \\
\text { throughput } \\
\text { (B.3) } \\
\end{array}$ & $\begin{array}{l}<\mathrm{B}-3-1>\text { Average tpmC (Transaction } \\
\text { per minute by council) } \\
<\mathrm{B}-3-2>\text { Average response time }\end{array}$ \\
\hline $\begin{array}{l}\text { Work efficiency } \\
\text { (B.4) }\end{array}$ & $\begin{array}{l}<\text { B-4-1> Input automation level (Input } \\
\text { interface level) }\end{array}$ \\
\hline \multicolumn{2}{|c|}{ IT infrastructure - Interoperability and standardization(C) } \\
\hline $\begin{array}{l}\text { Interoperability } \\
\text { among } \\
\text { ISs }(\text { C. } 1)\end{array}$ & $\begin{array}{l}<\mathrm{C}-1-1>\text { Average interoperability level } \\
\text { among battlefield management } \\
\text { information systems (MISs) } \\
<\mathrm{C}-1-2>\text { Average data interconnection } \\
\text { ratio among battlefield MISs } \\
<\mathrm{C}-1-3>\text { Average interoperability level } \\
\text { between battlefield MIS and resource } \\
\text { MIS } \\
<\mathrm{C}-1-4>\text { Average data interconnection } \\
\text { level between battlefield MIS and } \\
\text { resource MIS } \\
<\mathrm{C}-1-5>\text { Average interoperability level } \\
\text { among resource MISs } \\
<\mathrm{C}-1-6>\text { Average data interconnection } \\
\text { level among resource MISs }\end{array}$ \\
\hline $\begin{array}{l}\text { Standardization } \\
\text { of reference } \\
\text { information } \\
\text { (master data) } \\
\text { (C.2) }\end{array}$ & $\begin{array}{l}<\mathrm{C}-2-1>\text { Standardization ratio of } \\
\text { reference information/code data } \\
\text { (master data) }\end{array}$ \\
\hline
\end{tabular}

Table 2. Evaluation metrics for defense informatization level (continued).

\begin{tabular}{ll}
\hline $\begin{array}{l}\text { Interoperability } \\
\text { between }\end{array}$ & $<\mathrm{C}-3-1>$ Average interoperability level \\
weapon & between weapon systems and \\
systems and IS & $<\mathrm{C}-3-2>$ Average data interconnection \\
(C.3) & $\begin{array}{l}\text { ratio between weapon systems and } \\
\text { battlefield MIS }\end{array}$ \\
\end{tabular}

IT infrastructure - Information security(D)

Detection level <D-1-1> Intrusion detection ratio in (capability) of advance infringement incident(D.1)

Response level <D-2-1> Number of intrusion incidents (capability) of per year

infringement $\quad<D-2-2>$ Intrusion incident response incident(D.2) time

Recovery of $<$ D-3-1> Trace ratio of infringement infringement incidents

incident(D.3) <D-3-2> Recovery time after infringement incident

Informatization environment(E)

\begin{tabular}{ll}
$\begin{array}{c}\text { Efforts to } \\
\text { improve } \\
\text { informatization } \\
\text { capability(E.1) }\end{array}$ & $\begin{array}{c}<\text { E-1-1> Annual time of } \\
\text { informatization education }\end{array}$ \\
\hline $\begin{array}{l}\text { Informatization } \\
\text { master }\end{array}$ & $<$ E-2-1> Informatization master plan \\
plan(E.2) & \\
\hline $\begin{array}{l}\text { Efficient } \\
\text { execution of } \\
\text { budget(E.3) }\end{array}$ & $<$ E-3-1> Efficiency of budget execution \\
\end{tabular}

IS use(F)

Business <F-1-1> Ratio of tasks implemented by
informatization IS

(F.1)

Business $\quad<\mathrm{F}-2-1>$ Business use

use(F.2)

Table 3. Metrics for Speed (A.1).

\begin{tabular}{|c|c|}
\hline Item & Description \\
\hline $\begin{array}{l}\text { Evaluation } \\
\text { item }\end{array}$ & $\begin{array}{l}\text { Defense information network(A) }>> \\
\text { Speed(A.1) }\end{array}$ \\
\hline Metric & $\begin{array}{l}<\text { A-1-1> Average speed among main nodes } \\
<\text { A-1-2> Average speed between main node } \\
\text { and secondary node (branch line) } \\
<\text { A-1-3> Average speed between secondary } \\
\text { node and user }\end{array}$ \\
\hline Explanation & $\begin{array}{l}\text { Average speed among main nodes, the main } \\
\text { node and the secondary node, and the } \\
\text { secondary node and the user in the defense } \\
\text { information network }\end{array}$ \\
\hline $\begin{array}{l}\text { Measurement } \\
\text { method }\end{array}$ & $\begin{array}{l}\mathrm{X}=\frac{\text { measured speed of network }}{\text { maximum speed }(\text { designed speed })} \\
\mathrm{Y}=\frac{X}{\text { Target Value }} \times 100 \text { (satisfaction ratio of } \\
\text { network speed) }\end{array}$ \\
\hline $\begin{array}{l}\text { Data gathering } \\
\text { method } \\
\text { (Data } \\
\text { sources) }\end{array}$ & $\begin{array}{l}\text { - System } \quad \square \text { Data } \\
\square \text { Questionnaires } \quad \square \text { Interview } \\
※ \text { Measure with network management } \\
\text { systems (NMS) }\end{array}$ \\
\hline
\end{tabular}


The level evaluation for defense information network is performed using metrics for Speed (A.1), Traffic (A.2), and Availability/recovery time (A.3). Table 3 shows the evaluation metrics for Speed (A.1). These are average speed among main nodes (main lines), average speed between the main node and the secondary node (branch line), and average speed between the secondary node and the user (user network). The equation is the ratio of measured speed of network against maximum speed (designed speed) to the target ratio. The data for network speed can be acquired from network management systems (NMS).

Table 4. Metrics for Traffic (A.2).

\begin{tabular}{|c|c|}
\hline Item & Description \\
\hline $\begin{array}{l}\text { Evaluation } \\
\text { item }\end{array}$ & $\begin{array}{l}\text { Defense information network(A) >> } \\
\text { Traffic(A.2) }\end{array}$ \\
\hline Metric & $\begin{array}{l}<\text { A-2-1> Average traffic among main nodes } \\
<\text { A-2-2> Average traffic between main node } \\
\text { and secondary node (branch line) } \\
<\text { A-2-3> Average traffic between secondary } \\
\text { node and user }\end{array}$ \\
\hline Explanation & $\begin{array}{l}\text { Average traffic among main nodes, the main } \\
\text { node and the secondary node, and the } \\
\text { secondary node and the user in the defense } \\
\text { information network }\end{array}$ \\
\hline $\begin{array}{l}\text { Measurement } \\
\text { method }\end{array}$ & $\begin{array}{l}\mathrm{X}=\frac{\text { measured up/down traf fic in network }}{\text { available traf fic assigned to network }} \\
\mathrm{Y}=\frac{X \text {-Target Value }}{\text { Target Value }} \times 100 \text { (excess ratio of } \\
\text { traffic)* }\end{array}$ \\
\hline $\begin{array}{l}\text { Data gathering } \\
\text { method } \\
\text { (Data } \\
\text { sources) }\end{array}$ & $\begin{array}{l}\text { — System } \quad \square \text { Data } \\
\square \text { Questionnaires } \quad \square \text { Interview } \\
\text { ※ Measure average, minimum, and } \\
\text { maximum traffic of network with network } \\
\text { management systems (NMS) }\end{array}$ \\
\hline \multicolumn{2}{|c|}{$\begin{array}{l}\text { * Note. The scoring method of metrics in the form of excess } \\
\text { ratios: } 0 \% \text { or less, } 100 \text { points; } 0 \text { to } 20 \% \text { or less, } 80 \text { points; } 20 \\
\text { to } 40 \% \text { or less, } 60 \text { points; } 40 \text { to } 60 \% \text { or less, } 40 \text { points; } 60 \text { to } \\
80 \% \text { or less, } 20 \text { points; } 80 \% \text { or more, } 0 \text { points. }\end{array}$} \\
\hline
\end{tabular}

Table 4 describes metrics for traffic. The evaluation metrics for Traffic (A.2), like the metrics for Speed (A.1), measure a traffic on trunk, branch, and user network. These measure if an excessive traffic against a designed or estimated traffic occurs. The data for network traffic can be acquired from NMS.

The evaluation of Availability/recovery time (A.3) metric calculates availability with a probability that the network can be serviced without interruption, and manages data on network average recovery time to calculate availability. Table 5 presents a metric for network availability. The data for network availability can be acquired from NMS. The mean time to failure (MTTF) is average time of network service between failure of network and failure of network.
Table 5. $<$ A-3-1 $>$ Network availability metric.

\begin{tabular}{|c|c|}
\hline Item & Description \\
\hline $\begin{array}{l}\text { Evaluation } \\
\text { item }\end{array}$ & $\begin{array}{c}\text { Defense information network(A) }>> \\
\text { Availability/recovery time(A.3) }\end{array}$ \\
\hline Metric & $<$ A-3-1> Network availability \\
\hline Explanation & $\begin{array}{l}\text { A probability that the defense information } \\
\text { network can be serviced without } \\
\text { interruption }\end{array}$ \\
\hline $\begin{array}{l}\text { Measurement } \\
\text { method }\end{array}$ & $\begin{array}{l}\mathrm{X}=\text { MTTF } /(\mathrm{MTTF}+\mathrm{MTTR}) \\
\mathrm{Y}=\frac{X}{\text { Target Value }} \times 100 \text { (satisfaction ratio of } \\
\text { availability) } \\
※ \text { MTTF (Mean Time To Failure): average } \\
\text { time of network service } \\
※ \text { MTTR (Mean Time To Repair): average } \\
\text { time to recovery after network service } \\
\text { outage }\end{array}$ \\
\hline $\begin{array}{l}\text { Data gathering } \\
\text { method } \\
\text { (Data } \\
\text { sources) }\end{array}$ & $\begin{array}{l}\text { - System } \quad \square \text { Data } \\
\square \text { Questionnaires } \quad \square \text { Interview } \\
\text { ※ Measure with network management } \\
\text { systems (NMS) }\end{array}$ \\
\hline
\end{tabular}

Table 6. $<$ A-3-2 $>$ Recovery time metric.

\begin{tabular}{|c|c|}
\hline Item & Description \\
\hline $\begin{array}{l}\text { Evaluation } \\
\text { item }\end{array}$ & $\begin{array}{c}\text { Defense information network(A) }>> \\
\text { Availability/recovery time(A.3) }\end{array}$ \\
\hline Metric & $<$ A-3-2> Recovery time \\
\hline Explanation & $\begin{array}{l}\text { Average time to recovery after network } \\
\text { service outage }\end{array}$ \\
\hline $\begin{array}{l}\text { Measurement } \\
\text { method }\end{array}$ & $\begin{array}{l}\mathrm{X}=\mathrm{MTTR} \\
\mathrm{Y}=\frac{X \text {-Target Value }}{\text { Target Value }} \times 100 \text { (excess ratio of } \\
\text { recovery time) } \\
※ \text { MTTR (Mean Time To Repair): average } \\
\text { time to recovery after network service } \\
\text { outage }\end{array}$ \\
\hline $\begin{array}{l}\text { Data gathering } \\
\text { method } \\
\text { (Data } \\
\text { sources) }\end{array}$ & $\begin{array}{l}\text { - System } \quad \square \text { Data } \\
\square \text { Questionnaires } \quad \square \text { Interview } \\
\text { ※ Measure with network management } \\
\text { systems (NMS) }\end{array}$ \\
\hline
\end{tabular}

Table 6 shows the measurement method for the Recovery time metric. This calculates MTTR (Mean Time To Repair), and suggests providing service within target time of recovery. Shorter MTTR is better.

Other metrics are shown in appendix.

\section{CONCLUSION}

This study describes the defense informatization level evaluation system modified from the defense informatization evaluation methodology [4]. The proposed evaluation system for the defense informatization level measures in terms of IT infrastructure, informatization environment, and IS use [15]. This does not focus on a survey method but the direct measurement of the level if possible. The measurement effort should be put into the 
evaluation. The evaluation method that was being implemented by the government is accommodated as much as possible so that the efficient evaluation can be carried out while reducing the burden on the defense organization.

As with most researches and methodologies, there are limitations in the proposed evaluation system. It is necessary to set the target value for each metric. One also needs to consider metrics such as power usage effectiveness (PUE), which are used as metrics for US government data centers $[16,17]$. In addition, the study should have provided some cases or results applying the proposed evaluation system, but it does not due to a defense security issue.

Rather than waiting for the development of a sufficiently reasonable and theoretically complete evaluation system, it is better to complement the evaluation system by measuring the level of informatization. It is more significant to develop and apply the evaluation system that users can intuitively understand or use. Accumulated experiences with repetitive use of the evaluation system can lead to lessons learned and complementary needs, which can make the evaluation system more robust. Through such a virtuous cycle, the evaluation system of the defense informatization level and measurement metrics that are actively accepted by the stakeholders of the evaluation can be developed.

\section{Acknowledgements}

This manuscript is based on Research Report [15]. The authors wish to thank the editors and the anonymous reviewers for their careful reviews and constructive suggestions. Their suggestions helped strengthen the paper. All errors are the sole responsibility of the authors.

\section{REFERENCES}

[1] A. McAfee and E. Brynjolfsson, "Big data: The management revolution," Harvard Business Review, pp. 60-68, October 2012.

[2] Korea Ministry of National Defense (MND), Act on Establishment of Infrastructure for Informatization of National Defense and Management of Informational Resources for National Defense (Abbreviation: Act on Defense Informatization), Act No. 12553, http://elaw.klri.re.kr/kor_service/lawView.do?hseq=32 670\&lang=ENG, May 9, 2014.

[3] Korea Ministry of National Defense (MND), Defense Informatization Task Directive, MND Directive No. 2129, http://www.law.go.kr/행정규칙/국방정보화업 무훈령, Feb. 5, 2018. (In Korean)

[4] H. J. Kwon, J. S. Choi, S. T. Kim, H. J. Lee, and Y. P. Sung, "A study for improving an evaluation systems of defense informatization," Korea Institute for Defense
Analyses, Seoul, Republic of Korea, Research Report, Feb. 2012. (In Korean)

[5] W. H. DeLone and E. R. McLean, "Information systems success: The quest for the dependent variable," Information System Research, vol. 3, no. 1, pp. 60-95, 1992.

[6] W. H. DeLone and E. R. McLean, "The DeLone and McLean model of information systems success: A tenyear update," Journal of Management Information Systems, vol. 19, no. 4, pp. 9-30, Spring 2003.

[7] International Telecommunication Union, "Measuring the Information Society Report-Executive summary," ITU Publications, 2010-2015.

[8] International Telecommunication Union, "Measuring the Information Society Report-Executive Summary," ITU Publications, 2017.

[9] E. J. Lee and B. M. Ahn, "Evaluation of Informatization Level of ITU (IDI, ICT Development Index)," Korea Institute of S\&T Evaluation and Planning, Seoul, Republic of Korea, KISTEP Statistic Brief, 2013-26, 2013. (In Korean)

[10] International Telecommunication Union, "Measuring the Information Society Report," Volume 1, Statistical Reports, ITU Publications, 2018.

[11] Korea Ministry of the Interior and Safety, "2019 Central Government Department Self-evaluation (Public Administration Capability Part) Plan (Draft)," May 17, 2019. (In Korean)

[12] Office for Government Policy Coordination, Framework Act on Public Service Evaluation, Act No. 14839, July 26, 2017. (In Korean)

[13] Ministry of SMEs and Startups, and Korea Technology \& Information Promotion Agency for SMEs, "2018 Survey on the Information Level of Korean Small and Medium Enterprise," Daejeon, Republic of Korea, TIPA Research Report 19-01, May 31, 2019. (In Korean);

https://www.mss.go.kr/site/smba/foffice/ex/statDB/St ReportContentDetailView.do?gb=1\&reSeq=1712.

[14] G. G. Lim, D. C. Lee, H. J. Kwon, and S. R. Cho, “A case of developing performance evaluation model for Korean defense informatization," Information Systems Review, Vol. 19, No. 3, pp. 23-45, 2017. (In Korean)

[15] S. Lee, H. S. Jung, and S. J. Yoon, “An application with an evaluation methodology for defense informatization and validating the methodology," Sun Moon University, Asan, Republic of Korea, Research Report, Nov. 2012. (In Korean)

[16] U.S. Department of Energy, "Data center metering and resource guide," February 2017; https://datacenters.lbl.gov/sites/all/files/DataCenterMe teringandResourceGuide 02072017.pdf. 
[17] U.S. General Services Administration, Optimization Metrics,

2019;

https://www.gsa.gov/technology/government-it-

initiatives/dcoi/dcoi-data-center-

resources/optimization-metrics\#Energy\%20Metering.

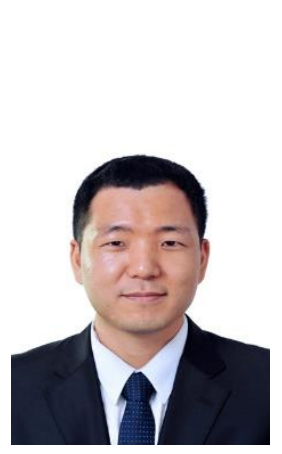

Authors

Seungbae Sim is a research fellow in the Center for Military Analysis and Planning at Korea Institute for Defense Analyses, Republic of Korea. He received the B.S. and M.S. degree in Industrial Systems Engineering from Yonsei University and Ph.D. degree in Information and Industrial Engineering from Yonsei University. His research interests include software policy, software productivity, analysis and audit of information system, IT project management, and data science.

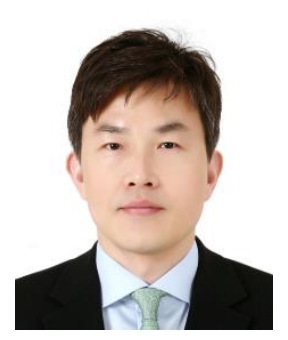

Sangho Lee is an associate professor in the Department of IT Management at Sun Moon University, Republic of Korea. He received his Ph.D. from Korea Advanced Institute of Science Technology (KAIST) and Master/Bachelor's degree at Sungkyunkwan University. His research interests are the business value of IT, the evaluation of IT investment projects, software engineering, and causality between IT investment and performance.

\section{APPENDIX}

Table A1. $<$ B-1-1 $>$ Average (maximum) CPU use ratio metric.

\begin{tabular}{|c|c|}
\hline Item & Description \\
\hline $\begin{array}{l}\text { Evaluation } \\
\text { item }\end{array}$ & $\begin{array}{l}\text { Computer systems(B) }>>\text { Server } \\
\text { utilization(B.1) }\end{array}$ \\
\hline Metric & <B-1-1> Average (maximum) CPU use ratio \\
\hline Explanation & Average CPU use ratio of IS server \\
\hline $\begin{array}{l}\text { Measurement } \\
\text { method }\end{array}$ & $\begin{array}{l}\mathrm{X}=\text { Daily } / \text { Monthly } / \text { Yearly average } \\
(\text { maximum) CPU use ratio } \\
\mathrm{Y}=\frac{X \text {-Target Value }}{\text { Target Value }} \times 100 \text { (excess ratio of } \\
\text { CPU use) }\end{array}$ \\
\hline $\begin{array}{l}\text { Data gathering } \\
\text { method } \\
\text { (Data } \\
\text { sources) }\end{array}$ & $\begin{array}{l}\text { System } \quad \square \text { Data } \\
\square \text { Questionnaires } \quad \square \text { Interview } \\
\text { ※ Measure with server management } \\
\text { systems (SMS) }\end{array}$ \\
\hline
\end{tabular}

Table A2. $<$ B-1-2 $>$ Average storage use ratio metric.

\begin{tabular}{ll}
\hline Item & Description \\
\hline Evaluation & Computer systems(B) $>>$ Server \\
item & utilization(B.1) \\
\hline Metric & $\langle\mathrm{B}-1-2\rangle$ Average storage use ratio \\
\hline
\end{tabular}

Table A2. $<$ B-1-2> Average storage use ratio metric (continued).

\begin{tabular}{|c|c|}
\hline Explanation & Average storage use ratio of IS server \\
\hline \multirow[t]{2}{*}{$\begin{array}{l}\text { Measurement } \\
\text { method }\end{array}$} & $\begin{array}{l}\mathrm{X}=\text { daily / monthly / yearly average storage } \\
\text { use ratio }\end{array}$ \\
\hline & $\begin{array}{l}\mathrm{Y}=\frac{X-\text { Target Value }}{\text { Target Value }} \times 100 \text { (excess ratio of } \\
\text { storage use) }\end{array}$ \\
\hline $\begin{array}{l}\text { Data gathering } \\
\text { method } \\
\text { (Data } \\
\text { sources) }\end{array}$ & $\begin{array}{l}\text { - System } \quad \square \text { Data } \\
\square \text { Questionnaires } \quad \square \text { Interview } \\
\text { ※ Measure with server management } \\
\text { systems (SMS) }\end{array}$ \\
\hline
\end{tabular}

Table A3. $<$ B-2-1 $>$ Server availability metric.

\begin{tabular}{|c|c|}
\hline Item & Description \\
\hline $\begin{array}{l}\text { Evaluation } \\
\text { item }\end{array}$ & $\begin{array}{l}\text { Computer systems(B) >> Server } \\
\text { availability(B.2) }\end{array}$ \\
\hline Metric & $<$ B-2-1> Server availability \\
\hline Explanation & $\begin{array}{l}\text { A probability that the server can be serviced } \\
\text { without interruption }\end{array}$ \\
\hline \multirow{4}{*}{$\begin{array}{l}\text { Measurement } \\
\text { method }\end{array}$} & $\mathrm{X}=\mathrm{MTTF} /(\mathrm{MTTF}+\mathrm{MTTR})$ \\
\hline & $\begin{array}{l}\mathrm{Y}=\frac{X}{\text { Target Value }} \times 100 \text { (satisfaction ratio of } \\
\text { availability) }\end{array}$ \\
\hline & $\begin{array}{l}※ \text { MTTF (Mean Time To Failure): average } \\
\text { time of server service }\end{array}$ \\
\hline & $\begin{array}{l}※ \text { MTTR (Mean Time To Repair): average } \\
\text { time to recovery after server service outage }\end{array}$ \\
\hline $\begin{array}{l}\text { Data gathering } \\
\text { method } \\
\text { (Data } \\
\text { sources) }\end{array}$ & $\begin{array}{l}\text { - System } \quad \square \text { Data } \\
\square \text { Questionnaires } \quad \square \text { Interview } \\
\text { ※ Measure with server management } \\
\text { systems (SMS) }\end{array}$ \\
\hline
\end{tabular}

Table A4. $<$ B-2-2 $>$ Server recovery time metric.

\begin{tabular}{|c|c|}
\hline Item & Description \\
\hline $\begin{array}{l}\text { Evaluation } \\
\text { item }\end{array}$ & $\begin{array}{l}\text { Computer systems(B) }>\text { Server } \\
\text { availability(B.2) }\end{array}$ \\
\hline Metric & $<$ B-2-2> Server recovery time \\
\hline Explanation & $\begin{array}{l}\text { Average time to recovery after server } \\
\text { service outage }\end{array}$ \\
\hline \multirow{3}{*}{$\begin{array}{l}\text { Measurement } \\
\text { method }\end{array}$} & $\mathrm{X}=\mathrm{MTTR}$ \\
\hline & $\begin{array}{l}\mathrm{Y}=\frac{X-\text { Target Value }}{\text { Target Value }} \times 100 \text { (excess ratio of } \\
\text { recovery time) }\end{array}$ \\
\hline & $\begin{array}{l}※ \text { MTTR (Mean Time To Repair): average } \\
\text { time to recovery after server service outage }\end{array}$ \\
\hline $\begin{array}{l}\text { Data gathering } \\
\text { method } \\
\text { (Data } \\
\text { sources) }\end{array}$ & $\begin{array}{l}\text { System } \quad \square \text { Data } \\
\square \text { Questionnaires } \quad \square \text { Interview } \\
\text { ※ Measure with server management } \\
\text { systems (SMS) } \\
\end{array}$ \\
\hline
\end{tabular}

Table A5. $<$ B-3-1 $>$ Average tpmC metric.

\begin{tabular}{ll}
\hline Item & Description \\
\hline $\begin{array}{c}\text { Evaluation } \\
\text { item }\end{array}$ & $\begin{array}{c}\text { Computer systems(B) }>>\text { Server } \\
\text { throughput(B.3) }\end{array}$ \\
\hline Metric & $\begin{array}{c}<\mathrm{B}-3-1>\text { Average tpmC (transaction per } \\
\text { minute by council) }\end{array}$ \\
\hline Explanation & $\begin{array}{c}\text { Average transaction processing speed of IS } \\
\text { server }\end{array}$ \\
\hline $\begin{array}{c}\text { Measurement } \\
\text { method }\end{array}$ & $\mathrm{X}=$ average tpmC \\
& $\mathrm{Y}=\frac{X}{\text { Target Value }} \times 100$ (satisfaction ratio of \\
& throughput speed) \\
\hline
\end{tabular}


Table A5. $<$ B-3-1> Average tpmC metric (continued).

\begin{tabular}{lll}
\hline Data gathering & $\square$ System & - Data \\
method & $\square$ Questionnaires & $\square$ Interview \\
(Data & $※$ Measure with server management \\
sources) & systems (SMS) and server specification \\
\hline
\end{tabular}

Table A6. $<$ B-3-2 $>$ Average response time metric.

\begin{tabular}{|c|c|}
\hline Item & Description \\
\hline $\begin{array}{l}\text { Evaluation } \\
\text { item }\end{array}$ & $\begin{array}{l}\text { Computer systems(B) }>>\text { Server } \\
\text { throughput(B.3) }\end{array}$ \\
\hline Metric & $\langle$ B-3-2> Average response time \\
\hline Explanation & $\begin{array}{l}\text { Average response time of IS server to client } \\
\text { requirement }\end{array}$ \\
\hline $\begin{array}{l}\text { Measurement } \\
\text { method }\end{array}$ & $\begin{array}{l}\mathrm{X}=\text { Average response time of IS server } \\
\mathrm{Y}=\frac{X \text {-Target Value }}{\text { Target Value }} \times 100 \text { (excess ratio of } \\
\text { response time) }\end{array}$ \\
\hline $\begin{array}{l}\text { Data gathering } \\
\text { method } \\
\text { (Data } \\
\text { sources) }\end{array}$ & $\begin{array}{l}\text { - System } \quad \text { Data } \\
\square \text { Questionnaires } \quad \square \text { Interview } \\
\text { ※ Measure with server management } \\
\text { systems (SMS) and server specification }\end{array}$ \\
\hline
\end{tabular}

Table A7. <B-4-1> Input automation level (Input interface level) metric.

\begin{tabular}{|c|c|}
\hline Item & Description \\
\hline $\begin{array}{l}\text { Evaluation } \\
\text { item }\end{array}$ & $\begin{array}{l}\text { Computer systems(B) >> Work efficiency } \\
\text { (B.4) }\end{array}$ \\
\hline Metric & $\begin{array}{l}\text { <B-4-1> Input automation level (Input } \\
\text { interface level) }\end{array}$ \\
\hline Explanation & Automation level of data input in IS \\
\hline \multirow{2}{*}{$\begin{array}{l}\text { Measurement } \\
\text { method }\end{array}$} & $\mathrm{X}=\frac{\# \text { of data input } \mathrm{w} \text { barcode } / R F I D / Q R \text { code }}{\text { total } \# \text { of data input }}$ \\
\hline & $\mathrm{Y}=\frac{X}{\text { Target Value }} \times 100$ \\
\hline $\begin{array}{l}\text { Data gathering } \\
\text { method } \\
\text { (Data } \\
\text { sources) }\end{array}$ & $\begin{array}{ll}\text { - System } & \text { Data } \\
\square \text { Questionnaires } & \square \text { Interview }\end{array}$ \\
\hline
\end{tabular}

Table A8. $<$ C-1-1> Average interoperability level among battlefield MISs metric.

\begin{tabular}{ll}
\hline Item & Description \\
\hline $\begin{array}{c}\text { Evaluation } \\
\text { item }\end{array}$ & $\begin{array}{c}\text { Interoperability and standardization(C) }>> \\
\text { Interoperability among ISs(C.1) }\end{array}$ \\
\hline Metric & $\begin{array}{c}<\text { C-1-1> Average interoperability level } \\
\text { among battlefield MISs }\end{array}$ \\
\hline Explanation & $\begin{array}{c}\text { Average Levels of Information System } \\
\text { Interoperability (LISI) among battlefield }\end{array}$ \\
& MISs \\
\hline Measurement & $\mathrm{X}=$ Average LISI among battlefield MISs \\
method & $\mathrm{Y}=\frac{X}{\text { Target Value }} \times 100$ (satisfaction ratio of \\
& interoperability) \\
\hline Data gathering & $\square$ System \\
method & $\square$ Questionnaires $\square$ Interview \\
(Data & $※$ Use the LISI result measured by Defense \\
sources) & Interoperability Center \\
\hline
\end{tabular}

Table A9. $<\mathrm{C}-1-2>$ Average data interconnection ratio among battlefield MISs metric.

\begin{tabular}{ll}
\hline Item & Description \\
\hline $\begin{array}{c}\text { Evaluation } \\
\text { item }\end{array}$ & $\begin{array}{c}\text { Interoperability and standardization(C) } \\
\text { Interoperability among ISs(C.1) }\end{array}$ \\
\hline Metric & $\begin{array}{c}<\text { C-1-2> Average data interconnection ratio } \\
\text { among battlefield MISs }\end{array}$ \\
\hline Explanation & $\begin{array}{c}\text { Average data interconnection ratio of } \\
\text { interface among battlefield MISs }\end{array}$ \\
\hline $\begin{array}{c}\text { Measurement } \\
\text { method }\end{array}$ & $\mathrm{X}=\frac{\# \text { of realized interconnection among ISs }}{\text { \# of required interconnection among ISs }}$ \\
& $\mathrm{Y}=\frac{X}{\text { Target Value }} \times 100$ (satisfaction ratio of \\
data interconnection)
\end{tabular}

Table A10. $<\mathrm{C}-1-3>$ Average interoperability level between battlefield MIS and resource MIS metric.

\begin{tabular}{|c|c|}
\hline Item & Description \\
\hline $\begin{array}{l}\text { Evaluation } \\
\text { item }\end{array}$ & $\begin{array}{l}\text { Interoperability and standardization }(\mathrm{C})>> \\
\text { Interoperability among } \operatorname{ISs}(\text { C. } 1)\end{array}$ \\
\hline Metric & $\begin{array}{l}<\mathrm{C}-1-3>\text { Average interoperability level } \\
\text { between battlefield MIS and resource MIS }\end{array}$ \\
\hline Explanation & $\begin{array}{l}\text { Average LISI between battlefield MIS and } \\
\text { resource MIS }\end{array}$ \\
\hline $\begin{array}{l}\text { Measurement } \\
\text { method }\end{array}$ & $\begin{array}{l}\mathrm{X}=\text { Average LISI between battlefield MIS } \\
\text { and resource MIS } \\
\mathrm{Y}=\frac{X}{\text { Target Value }} \times 100 \text { (satisfaction ratio of } \\
\text { interoperability) }\end{array}$ \\
\hline $\begin{array}{l}\text { Data gathering } \\
\text { method } \\
\text { (Data } \\
\text { sources) }\end{array}$ & $\begin{array}{l}\square \text { System } \quad \square \text { Data } \\
\square \text { Questionnaires } \square \text { Interview } \\
\text { ※ Use the LISI result measured by Defense } \\
\text { Interoperability Center }\end{array}$ \\
\hline
\end{tabular}

Table A11. $<$ C-1-4> Average data interconnection ratio between battlefield MIS and resource MIS metric.

\begin{tabular}{|c|c|}
\hline Item & Description \\
\hline $\begin{array}{l}\text { Evaluation } \\
\text { item }\end{array}$ & $\begin{array}{l}\text { Interoperability and standardization }(\mathrm{C})>> \\
\text { Interoperability among ISs(C.1) }\end{array}$ \\
\hline Metric & $\begin{array}{l}<\mathrm{C}-1-4>\text { Average data interconnection ratio } \\
\text { between battlefield MIS and resource MIS }\end{array}$ \\
\hline Explanation & $\begin{array}{l}\text { Average data interconnection ratio of } \\
\text { interface between battlefield MIS and } \\
\text { resource MIS }\end{array}$ \\
\hline $\begin{array}{r}\text { Measu } \\
\text { meth }\end{array}$ & $\begin{array}{l}\mathrm{X}=\frac{\# \text { of realized interconnection among } I S s}{\# \text { of required interconnection among ISS }} \\
\mathrm{Y}=\frac{X}{\text { Target Value }} \times 100 \text { (satisfaction ratio of } \\
\text { data interconnection) }\end{array}$ \\
\hline $\begin{array}{l}\text { Data gathering } \\
\text { method } \\
\text { (Data } \\
\text { sources) }\end{array}$ & $\begin{array}{l}\text { - System } \square \text { Data } \\
\square \text { Questionnaires } \square \text { Interview } \\
\text { ※ Measure the number of the realized } \\
\text { interconnection from ISs and the number of } \\
\text { the required interconnection from } \\
\text { Requirement of Capability (ROC) / } \\
\text { Information Exchange Requirement (IER) / } \\
\text { System/Subsystem Specification (SSS) }\end{array}$ \\
\hline
\end{tabular}


Table A12. $<\mathrm{C}-1-5>$ Average interoperability level among resource MISs metric.

\begin{tabular}{ll}
\hline Item & Description \\
\hline $\begin{array}{c}\text { Evaluation } \\
\text { item }\end{array}$ & $\begin{array}{c}\text { Interoperability and standardization }(\mathrm{C})>> \\
\text { Interoperability among ISs }(\mathrm{C} .1)\end{array}$ \\
\hline Metric & $<\mathrm{C}-1-5>$ Average interoperability level \\
& among resource MISs \\
\hline Explanation & $\begin{array}{c}\text { Average LISI (Levels of Information } \\
\text { System Interoperability) among resource } \\
\\
\text { MISs }\end{array}$ \\
\hline Measurement & $\mathrm{X}=$ Average LISI among resource MISs \\
method & $\mathrm{Y}=\frac{X}{\text { Target Value }} \times 100$ (satisfaction ratio of \\
& interoperability) \\
\hline Data gathering & $\square$ System \\
method & $\square$ Questionnaires $\square$ Data Interview \\
(Data & ※ Use the LISI result measured by Defense \\
sources) & Interoperability Center \\
\hline
\end{tabular}

Table A13. $<$ C-1-6> Average data interconnection ratio among resource MISs metric.

\begin{tabular}{|c|c|}
\hline Item & Description \\
\hline $\begin{array}{l}\text { Evaluation } \\
\text { item }\end{array}$ & $\begin{array}{l}\text { Interoperability and standardization }(\mathrm{C})>> \\
\text { Interoperability among ISs }(\mathrm{C} .1)\end{array}$ \\
\hline Metric & $\begin{array}{l}<\mathrm{C}-1-6>\text { Average data interconnection ratio } \\
\text { among resource MISs }\end{array}$ \\
\hline Explanation & $\begin{array}{l}\text { Average data interconnection ratio of } \\
\text { interface among resource MISs }\end{array}$ \\
\hline $\begin{array}{l}\text { Measurement } \\
\text { method }\end{array}$ & $\begin{array}{l}\mathrm{X}=\frac{\# \text { of realized interconnection among ISS }}{\# \text { of required interconnection among ISS }} \\
\mathrm{Y}=\frac{X}{\text { Target Value }} \times 100 \text { (satisfaction ratio of } \\
\text { data interconnection) }\end{array}$ \\
\hline $\begin{array}{l}\text { Data gathering } \\
\text { method } \\
\text { (Data } \\
\text { sources) }\end{array}$ & $\begin{array}{l}\text { - System } \square \text { Data } \\
\square \text { Questionnaires } \square \text { Interview } \\
※ \text { Measure the number of the realized } \\
\text { interconnection from ISs and the number of } \\
\text { the required interconnection from } \\
\text { Requirement of Capability (ROC) / } \\
\text { Information Exchange Requirement (IER) / } \\
\text { System/Subsystem Specification (SSS) }\end{array}$ \\
\hline
\end{tabular}

Table A14. $<$ C-2-1> Standardization ratio of reference information/code data (master data) metric.

\begin{tabular}{|c|c|}
\hline Item & Description \\
\hline $\begin{array}{l}\text { Evaluation } \\
\text { item }\end{array}$ & $\begin{array}{l}\text { Interoperability and standardization }(\mathrm{C})>> \\
\text { Standardization of reference information } \\
\text { (master data)(C. } 2)\end{array}$ \\
\hline Metric & $\begin{array}{l}<\mathrm{C}-2-1>\text { Standardization ratio of reference } \\
\text { information/code data (master data) }\end{array}$ \\
\hline Explanation & $\begin{array}{l}\text { The ratio of standardized code to total code } \\
\text { data/reference information }\end{array}$ \\
\hline $\begin{array}{l}\text { Measurement } \\
\text { method }\end{array}$ & $\begin{array}{l}\mathrm{X}=\frac{\# \text { of standardized code in defense ISs }}{\text { total } \# \text { of code data in defense ISs }} \\
\mathrm{Y}=\frac{X}{\text { Target Value }} \times 100 \text { (satisfaction ratio of } \\
\text { standardization) }\end{array}$ \\
\hline $\begin{array}{l}\text { Data gathering } \\
\text { method } \\
\text { (Data } \\
\text { sources) }\end{array}$ & $\begin{array}{ll}\text { a System } & \text { Data } \\
\square \text { Questionnaires } & \square \text { Interview }\end{array}$ \\
\hline
\end{tabular}

Table A15. $<$ C-3-1> Average interoperability level between weapon systems and battlefield MIS metric.

\begin{tabular}{ll}
\hline Item & Description \\
\hline $\begin{array}{l}\text { Evaluation } \\
\text { item }\end{array}$ & $\begin{array}{c}\text { Interoperability and standardization(C) } \\
\text { Interoperability between weapon systems } \\
\text { and IS(C.3) }\end{array}$ \\
\hline Metric & $<$ C-3-1> Average interoperability level \\
& between weapon systems and battlefield \\
& MIS \\
\hline Explanation & Average LISI (Levels of Information \\
& System Interoperability) between weapon \\
& systems and battlefield MIS \\
\hline Measurement & X $=$ Average LISI between weapon systems \\
method & and battlefield MIS \\
& Y $=\frac{X}{\text { Target Value }} \times 100$ (satisfaction ratio of \\
& interoperability) \\
\hline Data gathering & $\square$ System \\
method & $\square$ Questionnaires $\square$ Interview \\
(Data & ※ Use the LISI result measured by Defense \\
sources) & Interoperability Center \\
\hline
\end{tabular}

Table A16. $<$ C-3-2> Average data interconnection ratio between weapon systems and battlefield MIS metric.

\begin{tabular}{|c|c|}
\hline Item & Description \\
\hline $\begin{array}{l}\text { Evaluation } \\
\text { item }\end{array}$ & $\begin{array}{l}\text { Interoperability and standardization }(\mathrm{C})>> \\
\text { Interoperability between weapon systems } \\
\text { and IS(C.3) }\end{array}$ \\
\hline Metric & $\begin{array}{l}<\mathrm{C}-3-2>\text { Average data interconnection ratio } \\
\text { between weapon systems and battlefield } \\
\text { MIS }\end{array}$ \\
\hline Explanation & $\begin{array}{l}\text { Average data interconnection ratio of } \\
\text { interface between weapon systems and } \\
\text { battlefield MIS }\end{array}$ \\
\hline $\begin{array}{l}\text { Measurement } \\
\text { method }\end{array}$ & $\begin{array}{l}\mathrm{X}=\frac{\# \text { of realized interconnection }}{\# \text { of required interconnection }} \\
\mathrm{Y}=\frac{X}{\text { Target Value }} \times 100 \text { (satisfaction ratio of } \\
\text { data interconnection) }\end{array}$ \\
\hline $\begin{array}{l}\text { Data gathering } \\
\text { method } \\
\text { (Data } \\
\text { sources) }\end{array}$ & $\begin{array}{l}\text { System } \square \text { Data } \\
\square \text { Questionnaires } \square \text { Interview } \\
※ \text { Measure the number of the realized } \\
\text { interconnection from ISs and the number of } \\
\text { the required interconnection from ROC / } \\
\text { IER / SSS }\end{array}$ \\
\hline
\end{tabular}

Table A17. $<$ D-1-1 $>$ Intrusion detection ratio in advance metric.

\begin{tabular}{|c|c|}
\hline Item & Description \\
\hline $\begin{array}{l}\text { Evaluation } \\
\text { item }\end{array}$ & $\begin{array}{l}\text { Information security(D) }>>\text { Detection level } \\
\text { (capability) of infringement incident(D.1) }\end{array}$ \\
\hline Metric & $<\mathrm{D}-1-1>$ Intrusion detection ratio in advance \\
\hline Explanation & $\begin{array}{l}\text { The ratio of detecting the infringement } \\
\text { incident in advance }\end{array}$ \\
\hline $\begin{array}{l}\text { Measurement } \\
\text { method }\end{array}$ & $\begin{array}{l}\mathrm{X}=\frac{\# \text { of detection in advance }}{\text { total } \# \text { of infringement incident }} \\
\mathrm{Y}=\frac{X}{\text { Target Value }} \times 100 \text { (satisfaction ratio of } \\
\text { detection in advance) }\end{array}$ \\
\hline $\begin{array}{l}\text { Data gathering } \\
\text { method } \\
\text { (Data } \\
\text { sources) }\end{array}$ & $\begin{array}{l}\text { - System } \square \text { Data } \\
\square \text { Questionnaires } \square \text { Interview } \\
※ \text { Measure the total number of infringement } \\
\text { incident from target IS and the number of } \\
\text { detection in advance from the data of } \\
\text { Computer Emergency Response Team } \\
\text { (CERT) }\end{array}$ \\
\hline
\end{tabular}


Table A18. $<$ D-2-1 $>$ Number of intrusion incidents per year metric.

\begin{tabular}{|c|c|}
\hline Item & Description \\
\hline $\begin{array}{l}\text { Evaluation } \\
\text { item }\end{array}$ & $\begin{array}{l}\text { Information security(D) }>>\text { Response level } \\
\text { (capability) of infringement incident(D.2) }\end{array}$ \\
\hline Metric & $\begin{array}{l}<\text { D-2-1> Number of intrusion incidents per } \\
\text { year }\end{array}$ \\
\hline Expla & $\begin{array}{l}\text { The number of the infringement incident per } \\
\text { year in organization }\end{array}$ \\
\hline $\begin{aligned} & \text { Mea } \\
& \text { me }\end{aligned}$ & $\begin{array}{l}\mathrm{X}=\text { The number of the infringement } \\
\text { incident per year in organization } \\
\mathrm{Y}=\frac{X-\text { Target Value }}{\text { Target Value }} \times 100 \text { (excess ratio of } \\
\text { infringement incident occurrence) }\end{array}$ \\
\hline $\begin{array}{l}\text { Data gathering } \\
\text { method } \\
\text { (Data } \\
\text { sources) }\end{array}$ & $\begin{array}{l}\text { - System } \quad \square \text { Data } \\
\square \text { Questionnaires } \square \text { Interview } \\
※ \text { Measure the total number of infringement } \\
\text { incident from target IS }\end{array}$ \\
\hline
\end{tabular}

Table A19. $<$ D-2-2> Intrusion incident response time metric.

\begin{tabular}{ll}
\hline Item & Description \\
Evaluation & $\begin{array}{c}\text { Information security(D) }>>\text { Response level } \\
\text { (capability) of infringement incident(D.2) }\end{array}$ \\
\hline Metric & $<\mathrm{D}-2-2>$ Intrusion incident response time \\
\hline Explanation & $\begin{array}{c}\text { The response completion time following the } \\
\text { response procedure after the occurrence of } \\
\text { the infringement incident (the situation } \\
\text { ending time) }\end{array}$ \\
\hline $\begin{array}{l}\text { Measurement } \\
\text { method }\end{array}$ & $\begin{array}{l}\mathrm{X}=\text { Average processing time till the } \\
\text { situation ending after detecting the } \\
\text { infringement incident }\end{array}$ \\
& $\mathrm{Y}=\frac{X-\text { Target Value }}{\text { Target Value }} \times 100$ (excess ratio of \\
processing time)
\end{tabular}

Table A20. $<$ D-3-1 $>$ Trace ratio of infringement incidents metric.

\begin{tabular}{ll}
\hline $\begin{array}{l}\text { Item } \\
\text { item }\end{array}$ & $\begin{array}{c}\text { Description } \\
\text { infringement incident(D.3) }\end{array}$ \\
\hline Metric & $\begin{array}{c}<\mathrm{D}-3-1>\text { Trace ratio of infringement } \\
\text { incidents }\end{array}$ \\
\hline Explanation & $\begin{array}{c}\text { The success ratio of trace about the origin of } \\
\text { the infringement incident }\end{array}$ \\
\hline $\begin{array}{c}\text { Measurement } \\
\text { method }\end{array}$ & $\mathrm{X}=\frac{\text { \# of trace of infringement incident }}{\text { total \# of infringement incident }}$ \\
& $\mathrm{Y}=\frac{X}{\text { Target Value }} \times 100$ (success ratio of \\
trace)
\end{tabular}

Table A21. $<$ D-3-2> Recovery time after infringement incident metric.

\begin{tabular}{ll}
\hline Item & Description \\
\hline $\begin{array}{l}\text { Evaluation } \\
\text { item }\end{array}$ & $\begin{array}{c}\text { Information security(D) }>>\text { Recovery of } \\
\text { infringement incident(D.3) }\end{array}$ \\
\hline Metric & $\begin{array}{c}<\mathrm{D}-3-2>\text { Recovery time after infringement } \\
\text { incident }\end{array}$ \\
\hline Explanation & $\begin{array}{c}\text { Average time to recovery after infringement } \\
\text { incident }\end{array}$ \\
\hline $\begin{array}{c}\text { Measurement } \\
\text { method }\end{array}$ & $\begin{array}{c}\mathrm{X}=\text { Average time to recovery after the } \\
\text { infringement incident }\end{array}$ \\
& $\mathrm{Y}=\frac{X \text {-Target Value }}{\text { Target Value }} \times 100$ (excess ratio of \\
time to recovery)
\end{tabular}

Table A22. $<$ E-1-1 $>$ Annual time of informatization education metric.

\begin{tabular}{ll}
\hline Item & Description \\
\hline $\begin{array}{c}\text { Evaluation } \\
\text { item }\end{array}$ & $\begin{array}{c}\text { Informatization environment(E) }>>\text { Efforts } \\
\text { to improve informatization capability(E.1) }\end{array}$ \\
\hline Metric & $\begin{array}{c}<\text { E-1-1> Annual time of informatization } \\
\text { education }\end{array}$ \\
\hline Explanation & Annual time of informatization education \\
\hline $\begin{array}{c}\text { Measurement } \\
\text { method }\end{array}$ & $\begin{array}{c}\mathrm{X}=\text { Annual time of informatization } \\
\text { education per person in organization }\end{array}$ \\
& $\mathrm{Y}=\frac{\text { Min }(X, \text { Target Value })}{\text { Target Value }} \times 100$ (completion \\
& ratio of informatization education) \\
\hline $\begin{array}{c}\text { Data gathering } \\
\text { method }\end{array}$ & $\square$ System Q Data \\
(Data & $\square$ Questionnaires $\square$ Interview \\
sources) &
\end{tabular}

Table A23. $<$ E-2-1 $>$ Informatization master plan metric.

\begin{tabular}{|c|c|}
\hline Item & Description \\
\hline $\begin{array}{l}\text { Evaluation } \\
\text { item }\end{array}$ & $\begin{array}{c}\text { Informatization environment(E) }>> \\
\text { Informatization master plan(E.2) }\end{array}$ \\
\hline Metric & $<$ E-2-1> Informatization master plan \\
\hline Explanation & $\begin{array}{l}\text { Enterprise Architecture (EA) maturity level } \\
\text { measured by National Information Society } \\
\text { Agency (NIA) method and the execution } \\
\text { level of basic informatization plan }\end{array}$ \\
\hline \multirow[t]{2}{*}{$\begin{array}{l}\text { Measurement } \\
\text { method }\end{array}$} & $\begin{array}{l}X_{1}=(\text { EA maturity level }) / 5 \\
X_{2}=\frac{\# \text { of executed items in master plan }}{\text { total } \# \text { of items in master plan }}\end{array}$ \\
\hline & $\begin{array}{l}\mathrm{Y}=\left(\frac{w_{1} X_{1}}{\text { Target Value }}+\frac{w_{2} X_{2}}{\text { Target Value }}\right) \\
w_{1}+w_{2}=1\end{array}$ \\
\hline $\begin{array}{l}\text { Data gathering } \\
\text { method } \\
\text { (Data } \\
\text { sources) }\end{array}$ & $\begin{array}{ll}\square \text { System } & \square \text { Data } \\
\square \text { Questionnaires } & \square \text { Interview }\end{array}$ \\
\hline
\end{tabular}


Table A24. $<$ E-3-1 $>$ Efficiency of budget execution metric.

\begin{tabular}{ll}
\hline Item & Description \\
\hline $\begin{array}{l}\text { Evaluation } \\
\text { item }\end{array}$ & $\begin{array}{c}\text { Informatization environment(E) }>>\text { Efficient } \\
\text { execution of budget(E.3) }\end{array}$ \\
\hline Metric & <E-3-1> Efficiency of budget execution \\
\hline Explanation & $\begin{array}{c}\text { Efficiency level of budget execution: } \\
\text { executed budget against planned budget, } \\
\text { the ratio of budget for new IT project to } \\
\text { informatization budget, and the ratio of } \\
\text { informatization budget to total defense } \\
\text { budget }\end{array}$ \\
\hline $\begin{array}{l}\text { Measurement } \\
\text { method }\end{array}$ & $X_{1}=\frac{\text { executed budget }}{\text { planned budget }}$ \\
& $X_{2}=\frac{\text { budget for new IT project }}{\text { informatization budget }}$ \\
& $X_{3}=\frac{\text { informatization budget }}{\text { total defense budget }}$ \\
\hline $\begin{array}{l}\text { Data gathering } \\
\text { method } \\
\text { (Data } \\
\text { sources) }\end{array}$ & $\square=\left(\frac{w_{1} X_{1}}{\text { Target Value(TV })_{1}}+\frac{w_{2} X_{2}}{T V_{2}}+\frac{w_{3} X_{3}}{T V_{3}}\right) \times$ \\
\hline
\end{tabular}

Table A25. $<$ F-1-1 $>$ Ratio of tasks implemented by IS metric.

\begin{tabular}{ll}
\hline Item & Description \\
\hline $\begin{array}{c}\text { Evaluation } \\
\text { item }\end{array}$ & IS use(F) >> Business informatization(F.1) \\
\hline Metric & $<\mathrm{F}-1-1>$ Ratio of tasks implemented by IS \\
\hline Explanation & $\begin{array}{c}\text { Ratio of tasks implemented by IS to total } \\
\text { defense tasks (Informatization level of } \\
\text { defense tasks) }\end{array}$ \\
\hline $\begin{array}{c}\text { Measurement } \\
\text { method }\end{array}$ & $\mathrm{X}=\frac{\# \text { of tasks implemented by IS }}{\text { total \# of defense tasks }}$ \\
$\begin{array}{c}\text { Data gathering } \\
\text { method } \\
\begin{array}{c}\text { (Data } \\
\text { sources) }\end{array}\end{array}$ & $\mathrm{Y}=\frac{X \text { System }}{\text { Target Value }} \times 100$ \\
\hline
\end{tabular}

Table A26. <F-2-1> Business use metric.

\begin{tabular}{|c|c|}
\hline Item & Description \\
\hline $\begin{array}{l}\text { Evaluation } \\
\text { item }\end{array}$ & IS use(F) >> Business use(F.2) \\
\hline Metric & $<\mathrm{F}-2-1>$ Business use \\
\hline Explanation & $\begin{array}{l}\text { The ratio of tasks with IS in the defense } \\
\text { tasks }\end{array}$ \\
\hline \multirow[t]{3}{*}{$\begin{array}{l}\text { Measurement } \\
\text { method }\end{array}$} & $X_{1}=\frac{\text { working hour with IS }}{\text { total working hour }}$ \\
\hline & $X_{2}=\frac{\# \text { of tasks with IS }}{\text { total \# of tasks }}$ \\
\hline & 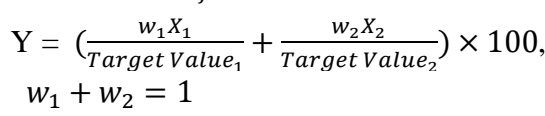 \\
\hline $\begin{array}{l}\text { Data gathering } \\
\text { method } \\
\text { (Data } \\
\text { sources) }\end{array}$ & $\begin{array}{ll}\square \text { System } & \square \text { Data } \\
\square \text { Questionnaires } & \square \text { Interview }\end{array}$ \\
\hline
\end{tabular}


Development of Evaluation System for Defense Informatization Level 